Jurnal The Messenger, Vol. 11, No. 1, January 2019, pp. 1-9

P-ISSN: 2086-1559, E-ISSN: 2527-2810

DOI: $10.26623 /$ themessenger.v11i1.876

\title{
Symbolic Interaction of The Deaf Students in Public School
}

\section{Interaksi Simbolik Siswa Tunarungu di Sekolah Umum}

\author{
Eka Wijaya Pranata ${ }^{1}$, Mochamad Chaerul Latif ${ }^{1}$, Fajriannoor Fanani ${ }^{1}$ \\ ${ }^{1}$ Department of Communication, Faculty of Information and Communication \\ Technology, Universitas Semarang, Jl. Soekarno Hatta Tlogosari Semarang 50196, \\ Central Java, Indonesia \\ *Corresponding author, e-mail: kamydelellis@gmail.com
}

\begin{abstract}
This study aims to know how symbolic interaction process happens to the deaf students who study in SD Maranatha 01 public school. Communication built by the deaf students to the teachers and other students who have good hearing will influence the changing of meaning and behavior. That's why the author is interested to analyze the symbolic interaction of the deaf students in public school, how the role of the teachers and other students in dealing with the deaf students to take their action and to adapt themselves in public school. The research method used in this study is descriptive qualitative conducted using observation, and interview techniques. The foundation used in this study is the theory of Symbolic Interactionism of George Herbert Mead. The conclusion of this research is; the behavior and symbolic formation happening to the deaf students of SD Maranatha 01 are influenced by the social process.

Keywords: Symbolic Interaction, Deaf Students, Public School, Hands Movement Symbol.
\end{abstract}

\begin{abstract}
Abstrak
Penelitian ini bertujuan untuk mengetahui bagaimana proses interaksi simbolik terjadi pada siswa tunarungu yang menempuh pendidikan di sekolah umum SD Maranatha 01. Komunikasi yang dibangun oleh siswa tunarungu terhadap guru dan siswa-siswa lain yang memiliki pendengaran baik, akan mempengaruhi perubahan makna dan perilaku. Itulah sebabnya penulis tertarik meneliti tentang interaksi simbolik siswa tunarungu di sekolah umum, bagaimanakah peran guru dan siswa-siswa lain yang memiliki pendengaran baik mempengaruhi siswa tunarungu untuk mengambil sikap dan menyesuaikan dengan situasi di sekolah umum. Metode penelitian yang digunakan dalam penelitian yaitu deskriptif kualitatif dengan menggunakan teknik observasi, dan wawancara. Landasan yang digunakan dalam penelitian ini adalah menggunakan teori Interaksionisme Simbolik dari George Herbert Mead. Kesimpulan dari penelitian ini adalah perilaku dan bentuk interaksi yang terjadi pada siswa tunarungu di SD Maranatha 01 dipengaruhi oleh adanya proses sosial.
\end{abstract}

Kata Kunci: Interaksi Simbolik, Siswa Tunarungu, Sekolah Umum, Simbol Gerakan Tangan.

\section{Copyright (C) 2019 Universitas Semarang. All rights reserved.}

\section{Introduction}

Language and communication are often seen as two sides of the same coin. Based on this view, the most important aspect of language is its use to communicate and the most important aspect of communication is the use of a language or code. The code that is mostly used in communication is the code that is spoken and written, or the code that deals with the use of words. There is still another code that is very important in the role of communication, namely nonverbal code (Nurdin, 2013).

In the first year of life, hearing is the most important part of human social, emotional and cognitive development. A mild or partial hearing loss can affect a 
person's ability to speak and understand language. For humans, hearing and language skills are very important tool for learning, playing and building social skills. For humans and many animals, the message of hearing becomes an important link to the environment and to each other. In the case of all auditory messages, the resulting vibration is carried through air or water. In order for the auditory signal to be efficient, the vibration must be detected, received and processed through a special organ that converts the data into electrical waves that can be interpreted by the brain (Ruben \& Stewart, 2013).

Physically, the deaf children are not different from the children in general, because people will know that someone carries hearing problem when speaking, the person speaks without sound or in low voice or unclear articulation, or even does not speak at all, and the person only gives hints. Murni Winarsih (Winarsih, 2007) states that 'the deaf person is someone who has a lack or loss of ability to hear either partially or completely due to the failure of some or all of the hearing devices, so that the child can not use his hearing instrument in daily life. This has an impact on his life in a complex manner, especially in language skills as a very important communication tool.' Meanwhile, according to Sunardi (Sunardi, 2007), 'In general the intelligence of the deaf children is potentially the same as the normal children, but functionally their development is influenced by the level of ability to speak, limited information, and the children abstraction. As result of the deafness, it inhibits the process of achieving broad knowledge.'

According to Iwin Suwarman in (Sadja'ah, 2005), the experts in the medical field, they stated that deaf children are categorized into two groups. First, hard of hearing is someone who still has the hearing in such a way that it is still enough to be used as a catcher for the hearing process as primary provision for mastering language skills and communication with others both with and without using hearing aids. Secondly, the deaf is someone who does not have such low sense of hearing that is unable to function as a tool for mastering language and communication, either with or without using hearing aids. The ability of deaf children who are classified as less hearing will be easier to get information so that their language skills will be better. Deaf children who have no hearing automatically difficult to get information so that their language skills are not good. Most of the deaf people take the formal education in Special Schools (Sekolah Luar Biasa) or schools for special needs children. This is because many deaf people feel that there are limitations in communication if they study in public schools.

SD Maranatha 01 is public school that accepts several students with hearing impairment. The aim of this school accepting the deaf students is to provide space and opportunities for the disabilities children to learn and develop with non-disabled (normal) children. With the existence of the deaf students in SD Maranatha 01, this shows that there are some children with hearing impairments who are brave to take formal education in public schools.

This study uses the Symbolic Interactionism of George Herbert Mead. This theory is used as a perspective in analyzing communication done by the deaf children to teachers and friends in school, because during the interaction, there are exchanges of symbols and signs both verbal and non-verbal. The most important symbols are words (languages), which can represent objects (things), ideas and affirmations, both speech (conversation, interview, discussion, lecture) or writing (letters, essays, articles, novels, poems, flyers) and can as well as non-verbal, such as through actions or gestures of the body (Mulyana, 2009).

Jurnal The Messenger, Vol. 11, No. 1, January 2019, pp. 1-9 
The understanding of Symbolic Interactionism according to Ralph LaRossa and Donald C. Reitzes in (West \& Turner, 2009), essentially explains the reference framework for understanding how humans, together with others, create symbolic world and how the world shapes human behavior.

Symbolic interaction is based on ideas about individuals and their interactions with society. The essence of symbolic interaction is an activity that is human characteristic, namely communication or exchange of symbols that are given meaning. The symbolic interaction perspective seeks to understand human behavior from the point of view of the subject. This perspective suggests that human behavior should be seen as a process that allows people to shape and regulate their behavior by considering the expectations of others who become their interaction partners (Soekanto, 2001).

Symbolic interaction has been refined to be used as one of the sociological approaches by Herbert Blumer and George Herbert Mead (in Salim, 2008), which holds the view that humans are individuals who think, feel, give understanding to every situation, gives rise to reactions and interpretations to every stimulus faced. This event is carried out through the interpretation of symbols or meaningful communication carried out through motion, language, sympathy, empathy, and gives birth to other behaviors that show reaction or response to stimuli that come to him.

Symbolic interaction is defined as the on-going use of language and gestures in anticipation of how the other will react in a conversation) (Griffin, 2011). Furthermore, the symbol of gesture is used by the deaf people to express all forms of emotion inside them so that they can be understood by their interlocutors. So that the output is expected that communication conducted by children with hearing impairment with those around them can run effectively and shape a behavior and meaning changes.

'Mind, Self and Society' is another famous work of George Hubert Mead (West \& Turner, 2009). Each concept is outlined through:

1. Mind

Mead defines thought (mind) as the ability to use symbols that have the same social meaning, and Mead believes that humans must develop thoughts through interaction with others. (a) Language is a system of verbal and non-verbal symbols arranged in patterns to express thoughts and feelings shared. Using language and interacting with others have developed thoughts. Closely related to the concept of mind is (b) thought, which is stated by Mead as an inner conversation. According to Mead, one of the most important activities that people solve through thinking is (c) role taking or the ability to symbolically put themselves in the fantasy of others. This process is also called perspective taking because this condition requires that someone stop his own perspective on an experience and instead imagine it from someone else's perspective.

2. Self

Mead defines self as the ability to reflect himself from the perspective of others. Looking glass self is one's ability to see oneself in the reflection from the views of others. Cooley believes in three development principles that are linked to the mirror of self: (1) we imagine how we look in the eyes of others, (2) we imagine their judgments about our appearance, (3) we feel hurt or proud based on the personal feeling.

3. Society

Mead stated that interaction takes place in a dynamic social structure. Head defines society as social relation network created by humans.

In the writer's opinion, the symbolic interactionism approach is one approach that leads to the interaction that uses symbols in communicating, whether through motion, 
language and sympathy, so that will emerge a response to the stimuli that come and make humans react or act to that stimuli.

\section{Methodology}

This research was qualitative approach regarding the description data (Bogdan \& Taylor in (Moleong, 2010)). This study was conducted in elementary school in Semarang that is SD Maranatha 01 located at J1. Sri Rejeki Raya I, Kalibanteng Kidul, West Semarang, Semarang City, Central Java 50149. The reason for choosing the location in SD Maranatha 01 is because it is very rare for public schools in Semarang to accept disabilities students.

The subject of the study is the source of where to obtain research description or someone or something about who wants to get information. As for the subjects of this study are the deaf children who study in public schools. While the objects of this research are the problems to be examined or problems to be solved or limited through research. The object in this study is the symbolic interaction used by the deaf children in interacting with the people around them in school.

The researchers used purposive sampling technique in this study. This technique includes people selected on the basis of certain criteria made by the researchers based on the research objectives, which can be called as informants. The technique of collecting data is observation. The researchers use passive participant observation for data collection technique, that is the researchers come in place of thye informant activity to be observed, but he is not involved in the activity.

The researchers use unstructured interview technique, because in unstructured interview the researchers are given freedom in asking through the findings obtained from the informant response whose essence is to get the understanding of a phenomenon. To support this research, the researchers conducted review and observation toward some of the previous research literature that were in line with the researchers' study. The following are some similar references with the researchers' study, namely:

The first study with the title 'Symbolic Interaction with Deaf Children in Dharma Asih Special School (SLB), Pontianak'. The researcher is Aliyah Nur'aini Hanum, a graduate student of the Communication Science Study Program at the Faculty of Social and Political Sciences, Universitas Tanjungpura, Pontianak. This study uses the theory of symbolic interactionism that see how the use of verbal and non-verbal languages, problem solving, communication model and the process of self, mind and society that occurs in children with hearing impaired and their environment. The results of the study show that the symbolic interactionism model includes verbal and non-verbal communication patterns that occur between persons with hearing impairment and their environment. The similarity of this study with researchers' study is that both use the same theoretical approach namely uses the theory of symbolic interactionism used by the deaf children to communicate with people around the school both teachers and school friends. The difference of the researchers' study with Aliyah Nur'aini Hanum's study is that Aliyah Nur'aini's research examined the symbolic interaction of the deaf children in the Special School where SLB (Sekolah Luar Biasa) is a school devoted to persons with disabilities including deaf and the learning method is adjusted to their needs, while the researchers study is more to the symbolic interactions of deaf children in public schools where the people around them are normal human beings who have 
good hearing, and the method of learning is in accordance with the method of learning in public schools.

The second study with the title 'Interpersonal Communication between Teachers and Deaf Children in Improving the Quality of Prayers'. The writer is Eko Wahyudi, a graduate student of Islamic Communication and Broadcasting Sciences at the Faculty of Da'wah and Communication Sciences, UIN Syarif Hidayatullah, Jakarta. In this study, the theory used is symbolic interactionism. This theory is one of the communication theories that emphesizes the symbol, because the symbol can express a signal in the form of feelings and thoughts. In this study, interpersonal communication was applied using demonstration method balanced by oral method. In order for this implementation to be effective it must be supported by adequate infrastructure. The difference between Eko Wahyudi's study and the researchers' study lies in the object of research where Eko Wahyudi's research focuses on symbolic interaction between teachers and deaf children in improving prayer, while the researchers' study is more on the symbolic interaction used by deaf children in studying in public schools.

\section{Result and Discussion}

Based on the results of the study above, of the six research informants the process of symbolic interaction begins when the deaf students adapt and adjust themselves in public schools where the people in public schools are normal teachers and students. The symbolic interaction process begins when students follow the teaching-learning process, where the teacher gives material in front of the class by using the usual teaching method, such as teaching normal students. In this study the focus of the study is starting from how the process of symbolic interaction occurs in the deaf students studying in public schools where the output contains a meaning for the deaf students in the society. Researchers in this study relate the things found in the field to 3 (three) points of view in the process of symbolic interaction.

1. Mind

According to George Herbert Mead, mind is not an object but a social process. Mind or commonly regarded as common sense is identical with the use of symbols. In this study gesture and language symbols come out through social processes carried out by the deaf students with their environment in public school. As an example that happened in the second grade class by informant 1 named Echa, when Echa wanted to ask her friend if the work had finished or not, Echa pointed to a book belonging to her friend then showed the hand symbol with the index finger and thumb forming a circle, while the other fingers were raised that means 'OK' or 'had finished'. The same thing was also experienced by informant 2, namely fourth grade deaf student named Septya. In this process, Septya usually directly asks the teacher or friend by asking while using the hand gesture symbol using the symbol of the number in question, then raising both hands at shoulder level with the palm facing up which means 'what' or 'how'.

Using the language symbol means that we need to know or have the same language, because the symbol is identical with the same response. As happened in class IV experienced by informant 3 (Mrs. Ani) and friends of informant 2 (Septya) who already have the same understanding of the body movement symbol when interacting with informant 2 (Septya). When informant 3 (Mrs. Ani) and students in grade IV would invite informant 2 (Septya) to communicate, they held the neck with their index finger and thumb, this shows that people would invite informant 2 (Septya) to speak. In addition to holding the neck, body touch also indicated that other people wanted to 
invite informant 2 (Septya) to speak, but if the distance is rather far apart and it is impossible to touch the body, before holding the neck must be preceded by waving two hands with the hand raised parallel to the face. This also indicated that other people who did the movement wanted to invite informant 2 (Septya) to speak.

Mind has the flexibility of thought which means that when the symbol is incomprehensible to the interlocutor, it is certain that the interlocutor will try to guess what is meant in the conversation so that there is still interaction even though the response will be slightly hampered. As stated by informant 3 (Mrs. Ani) that the language used came out by itself where we tried to use mouth movements and hand symbols which later the deaf students could receive, and when the deaf students still did not understand, then they had to keep trying until the deaf students really understood even though they had to use various symbols of different gestures.

The example above is in line with what was said by Mead. Mead defines mind as the ability to use symbols that have the same social meaning, and Mead believes that humans must develop their minds through interaction with others (West \& Turner, 2009).

2. Self

Mead defines self as the ability to reflect on oneself from the perspective of others. Self-mirroring (looking glass self) is one's ability to see oneself in reflection from the views of others. Deaf students are well aware that they are not the same as normal students who can hear. Normal students do not understand sign language at all. Because of the awareness the deaf students in SD Maranatha 01 try to adjust themselves as much as possible using their mouth with the support of gestures. As done by informant 1 (Echa), the symbol of hand movement used is not the symbol of hand movements such as sign language that has verbal meaning, but she uses the symbol of hand movements that are generally understood by normal people easily. So this makes interacting with others who do not understand sign language easy. By using oral lips that are clear and the support of the symbol of hand movements become habit for informant 1 (Echa) in interacting with the teachers and friends in school. In this case the informant 1 (Echa) has an inner drive to adjust to the surrounding circumstances so that other people (teachers and friends) see that deaf children are actually very good and easy to communicate even though they have to use different methods. But basically deaf students can grasp what others are talking about by transferring the sense of hearing to the sense of seeing.

In addition, in this study a meaning that deaf students are not like children who have mental retardation is found, deaf students in SD Maranatha 01 have quite good grade for the subjects thought. Like informant 2 (Septya) who has pretty good grade in mathematics. It shows that deaf students actually can receive materials taught by classroom teachers in public schools. The same thing happened to informant 1 (Echa) who had achievements in Tae Kwon Do championship. Informant 1 (Echa) won the best achievement in the 3rd place in the national level of Tae Kwon Do championship in the category of children. With the achievements of informant 1 (Echa) in Tae Kwon Do championship and the good mathematics grade of informant 2 (Septya), these became a symbol of the assessment of others on the deaf. Although the appearance of the speaking style of the deaf is not perfect, halting and difficult to understand, but the deaf have the same intelligence as normal people.

Deaf students in SD Maranatha 01 seem unlike deaf children, they tend to be very confident and able to mingle with their normal friends. In socializing, there are never 
discriminatory attitude and bullying for students who have physical disabilities, especially deaf students. Other normal students treat deaf students like normal people in general, there are no visible obstacles and difficulties that interfere their friendship. This shows that deaf students in SD Maranatha 01 are very comfortable with their school environment and feel proud of themselves by showing the grade of subjects that tend to be good even though they have hearing limitations. This is also supported by the opinion of informant 4 (Mrs. Duwi) who thinks that deaf children are not like the views of many people. Views that exist in the community say that deaf children are children who have difficulties in receiving information because of limited hearing, this will interfere the communication process and have an impact on the behavior of the output received from the communication process. But in this case informant 4 (Mrs. Duwi) argued that the way to interact of deaf students with their friends seemed like there was no limit, it was like normal students. This is because there is a sense of pride and selfconfidence within the deaf students.

If we discuss George Herbert Mead's concept of self, then it will not be separated from Mead's discussion of 'I' and 'me'. 'I' reacts to 'me' which organizes a set of other people's attitudes that he takes into his own attitude. In other words, 'I' is the acceptance of others that is generalized. In this case the deaf students take the attitude of normal friends and teachers in schools where deaf students are forced to become part of the public school environment by adjusting the habit in school, both attitudes in teaching and learning process and how to interact. ' $\mathrm{I}$ ' is currently a process for deaf students in SD Maranatha 01 in socializing with the community. Unlike ' $I$ ', 'me' allows individuals to live comfortably in social life. In this case, according to its characteristics, people with hearing impairment are people who are poor in vocabulary and lack of mastery of rhythm and style of language, so that people with hearing impairment are actually more comfortable to not sound and prefer using sign language. Thus ' $\mathrm{I}$ ' and 'me' are part of the whole social process and allow both individuals and societies to function effectively. 3. Society

The behavior and form of interaction that occurs in deaf students in SD Maranatha 01 is influenced by the existence of social process. Public schools are dominated by normal students which ultimately affect the deaf students how to take position and role in interacting with people in the school environment where all are good hearing people. Likewise, the presence of deaf students in SD Maranatha 01 also influences teachers and other normal students how to behave towards deaf people. This is in accordance with Mead's assumption that interaction takes place in a dynamic social structure. Culture and social process influence humans and groups and hence social structure is determined through the types of social interactions. This theory considers how societal and cultural norms become individual behavior (West \& Turner, 2009).

\section{Conclusion}

Based on the results of research and discussion of this study, it can be concluded that the interaction that occurs between deaf students and teachers and friends in public schools goes well. Language and hand movements become a symbol for deaf students in delivering messages to the people around them. By speaking using their mouth and supported by non-verbal hand movements is very helpful and facilitates the communication pattern between the deaf students with the teachers and their friends in the teaching and learning process in the classroom. In this way the teachers and other normal students easily catch and receive messages from what the deaf students 
delivered. In this way too the teacher and other friends make it easier to invite the deaf students to communicate. With this process, the deaf students have carried out symbolic interaction by the way of thinking and applying their unique abilities in responding to situations in public school environment that is largely dominated by normal people who have good hearing.

Circumstances force the deaf students not to use sign language they normally use with their fellow deaf people, but they use verbal language by speaking with their mouths and supported by hand movements that are easily understood by normal people. With this process there is a modification or changing the meaning and symbol in the community where previously the community (specifically the teachers and other normal students in public schools) considered that people with hearing impairment are people who are very difficult to communicate with and have difficulty in receiving material thought in public school. Now that judgment changes that deaf students can receive messages and things by using the sense of seeing. With the sense of seeing, deaf people observe every mouth motion, facial expression and gesture to capture information from their interlocutor. This is also evidenced by the grade of subjects that deaf students have showing that students with hearing impairment can compete with other normal students. From there it can also be understood that students with hearing impairment actually have the same potential as normal people if they get support from the surrounding environment.

Meanwhile, this study uses qualitative descriptive research method. This method is used as problem-solving procedure that is investigated by describing the state of the subject and object of research namely deaf students, teachers and other students in SD Maranatha 01. Research findings and interviews are processed to obtain the description of the research on 'Symbolic Interaction of the Deaf in Taking Education in Public Schools' clearly obtained information about the meaning and symbol of the deaf students in interpreting themselves and addressing the surrounding environment in public schools.

\section{Acknowledgement}

The writers would like to thank SD Maranatha 01 Semarang, specifically to the teachers (Mrs. Ani, Mrs. Duwi, Mrs. Tyas) and the deaf students (Echa and Septya) who are willing to cooperate and sincerely assist in this research process so that this research can be completed properly.

\section{References}

Griffin, E. (2011). A First Look at Communication Theory. New York: McGraw-Hill.

Moleong, L. J. (2010). Metodologi Penelitian Kualitatif. Bandung: PT. Remaja Rosdakarya.

Mulyana, D. (2009). Ilmu Komunikasi; Suatu Pengantar. Bandung: PT Remaja Rosdakaraya.

Nurdin, A. (2013). Pengantar Ilmu Komunikasi. Surabaya: Mitra Media Nusantara.

Ruben, B. D., \& Stewart, L. P. (2013). Komunikasi dan Perilaku Manusia. Depok: PT Raja Grafindo Persada.

Sadja'ah, E. (2005). Pendidikan Bahasa bagi Anak Gangguan Mendengar. Jakarta: Departemen Pendidikan Nasional.

Salim, A. (2008). Pengantar Sosiologi Mikro. Yogyakarta: Pustaka Pelajar.

Soekanto, S. (2001). Sosiologi Suatu Pengantar. Jakarta: PT Raja Grafindo Persada. 
Sunardi. (2007). Intervensi Dini Anak Berkebutuhan Khusus. Jakarta: Departemen Pendidikan dan Kebudayaan.

West, R., \& Turner, L. H. (2009). Pengantar Teori Komunikasi: Analisis dan Aplikasi. Jakarta: Salemba Humanika.

Winarsih, M. (2007). Intervensi Dini bagi Anak Tuna Rungu dalam Pemerolehan Bahasa. Jakarta: Departemen Pendidikan dan Kebudayaan. 